\title{
Integrated Geology and Geochemical Analysis of Eruku Basement Complex, Southwestern Nigeria
}

\author{
${ }^{*}$ M. Lawal, ${ }^{3 S}$. A. Ayomaya, ${ }^{3}$ J. 0. Ojero, ${ }^{2}$ A. Muhammad, ${ }^{1}$ N. A. Yelwa, ${ }^{1} \mathrm{~J}$. Bello and ${ }^{1}$ A. Bello \\ ${ }^{1}$ Department of Geology, Usmanu Danfodiyo University, Sokoto \\ 2Department of Geography Shehu Shagari College of Education, Sokoto \\ ${ }^{3}$ School of Earth and Environmental Science, University of Manchester, UK \\ [Corresponding Author: E-mail: awalmuktar@yahoo.com]
}

\begin{abstract}
Eruku, located within Osi which is part of the southwestern Nigerian Basement Complex plays host to principal exposures of Precambrian - Paleozoic crystalline rocks in the region. Detailed geological mapping revealed the area to comprise essentially of migmatite - banded gneiss complex and diorites and minor rock types that include pegmatite and quartz veins with associated superficial stream deposits occurring proximally along channels in the vicinity. While efforts have been committed to regional mapping, petrography and geochemistry of rocks in the region, little attention was paid to detail delineations and integrating the observed associated stream sediments. This study employs detailed geological mapping, granulometric analysis and the use of XRF and ICP - MS to establish the geology and geochemical properties of the rocks and surrounding deposits in the area. Migmatitic rocks predominates the southwestern and part of the northwest, while the granite gneisses with some occurrence of diorite are mainly confined to the northeastern part of the study area. Granulometry of the sediments revealed a predominantly medium - coarse grained, poorly sorted leptokurtic sands, indicating products of in-situ weathering of host rocks. Geochemical analysis supports a strong correlation between the rocks and the sediments. The study is useful as guide to regional mapping and is applicable in geochemical prospecting of minerals.
\end{abstract}

Keywords: Basement complex, migmatite - gneiss complex, stream sediments, granulometric analysis, elemental abundance, southwestern Nigeria

\section{INTRODUCTION}

The Basement complex of Nigeria, which is part of the West African Precambrian to Early Paleozoic orogeny, comprises of Precambrian crystalline rocks with associated infolded Schist belts. The Southwestern Nigeria (Figure 1) that hosts the study area (Eruku) is generally represented by series of older metasediments and gneisses that are known to be of Precambrian to Lower Paleozoic age (Oyawoye, 1972). Eruku is located in the Osi area sheet 224 SE $(1: 27,000)$ of Southwestern Nigeria covering approximately $65.54 \mathrm{~km} 2$ (Figure 2). It is situated within latitudes $8004^{1} \mathrm{~N}$ and $8^{00} 09^{1} \mathrm{~N}$ and longitudes $5^{0} 25^{1} \mathrm{E}$ and $5^{02} 2^{1} \mathrm{E}$, and is essentially made up of migmatites and granite gneisses with some miscellaneous superficial deposits. The migmatitic rocks predominate in the northwestern and southwestern parts, while the granite gneisses with some occurrence of diorite dominate the northeastern part of the study area.
The geology and geochemistry of the Southwestern Nigerian Basement complex have been reported by many researchers (Oyawoye, 1972; Rahaman; 1976; Anifowose, 2007; Ayodele, 2015). Oyawoye (1972) classification typifies the rocks in this region as older granites, migmatitic complex, metasedimentary series of schists, amphibolites, marble and calc silicates, as well as miscellaneous rocks that include charnockite, diorite, gabbro and metagabbro, potassic syenites and dolerite. General trend of north-east and south-west have been established for the region. Foliations in the region are predominantly tectonic in origin with evidence of pre-existing structures being replaced by deformational structures (Odeyemi et al., 1999).

Most of the studies carried out in the area focused on outcrops, petrography, 
geochemistry and structural analysis of the rocks with less regard for the linkage between the crystalline outcrops and the surrounding superficial deposits. Therefore this study attempts to provide detailed geological mapping, granulometric analysis of the superficial and geochemical properties of the rocks and surrounding deposits in the Eruku area.

\section{Geologic setting}

The Basement complex of Nigeria is part of the West African craton of Precambrian to Early Paleozoic orogeny (Oyawoye, 1972) that has been affected by supracrustal plutonics. The area lies between $60 \mathrm{~N}$ and $120 \mathrm{~N}$ latitudes and $4^{\circ} \mathrm{E}$ and $12^{\circ} \mathrm{E}$ longitudes. It extends westwards and into the Dahomey superbasin that includes the Togo and Ghana regions. It also extends Northward into Niger Republic, eastward into the Cameroon, and is overlain by a Mesozoic Recent rocks of the coastal basins of Dahomey and Niger (Grant, 1969; Ajibade and Wright, 1989). The Nigerian Basement complex (Figure 1 ) is generally outcropped in the North-central region where it occurs as continuous shields, and in the Southwest and the Eastern Nigeria where they are separated by sedimentary deposits (Ayodele, 2015). The outcropped crystalline rocks observed today are resting on pre-pan african ancient basement of sialic crust.

The crystalline rocks constitute the basement complex of Nigeria covering about half of the country's landmass; the rest of the country is covered by sedimentary deposit. The basement complex is classified broadly into three; the gneiss-migmatite complex, the metasedimetary schist belt and the older granite. The gneissmigmatite complex are composed of Archean (3000Ma) and Earliest Proterozoic (2000Ma) ages (Oversby, 1975; Dada et al., 1995) and forms the base upon which the metasedimentary Schist belt is deposited. The gneiss-migmatite complex together with the schist sequences were affected by the Pan African tectonic deformation of $600 \mathrm{Ma}$ to produce the observed conformable relationships (Annor, 1986 and Ajibade, 1987 in
Ayodele, 2015), thereby making relative dating and origin of these rocks difficult to ascertain. Hence the older granites which are essentially suites of discordant granitoids including granites, granodiorites, syenites and adamellites were emplaced due the Pan African orogeny (Kennedy, 1964). The Nigerian Basement complex suffered series of tectonic events that transformed them into rocks that were classified into six lithological groups by Rahman (1988) as follows: (i) migmatitegneiss-quartzite complex, (ii) the schist belts, (iii) the charnokitic rocks, (iv) the older granites, (v) Volcanic, gabbroic and dioritic rocks and (vi) the unmetamorphosed miscellaneous rocks including dolerite, syenites and dykes.

The Eruku area in Osi region of Southwestern Nigeria Basement complex exhibited three classes of rocks (Figure 3) - (i) major rock types comprising of migmatite - banded gneiss complex and diorites and (ii) minor rock types that include pegmatite and quartz veins, and (iii) a set of basically superficial deposits also occur in the area. The banded gneiss complex consists of isolated domes low-lying ridges composed of an assemblage mainly of quartz, biotite, muscovite and hornblende. The Diorites are plutonic composed essentially of oligoclase or andesine, biotite, hornblende and / or pyroxene and are occurring as undeformed small bodies of rocks or stocks with the dark minerals such as andesine, biotite, and hornblende predominating. The pegmatitic rocks occur as simple veins and dykes and situated mostly within the gneisses. Most of the pegmatite veins, which comprise of coarsegrained quartz and feldspar minerals with some biotite, averaged about $8 \mathrm{~m}$ in length and $30 \mathrm{~cm}$ in width, and are believed to be members of the older granites (Rahaman, 1976). The quartz veins and lenses occur in almost all the major rock types in the area and vary in thickness from a few millimetres to a metre, showing great irregularities in their morphologies. The superficial deposits refers to the unconsolidated and loosely consolidated deposits that often occurring proximal to the base of the Basement complex outcrops. They appear as by-products of denudation of pre-existing rocks; they consist 
mainly of gravely, sandy, silty, clay and lateritic materials occurring mainly in major valleys. These deposits are dominated by quartz and feldspar.

Most of the outcrops have been deformed. Associated structures are believed to be of tectonic origin with predominantly quartzose and feldspathic intrusive rocks with varying degree of jointing (Anifowose et al., 2007). General trend of north-east and south-west have been established for the region. Foliations in the region are predominantly tectonic in origin with evidence of pre-existing structures being replaced by deformational structures (Odeyemi et al., 1999).

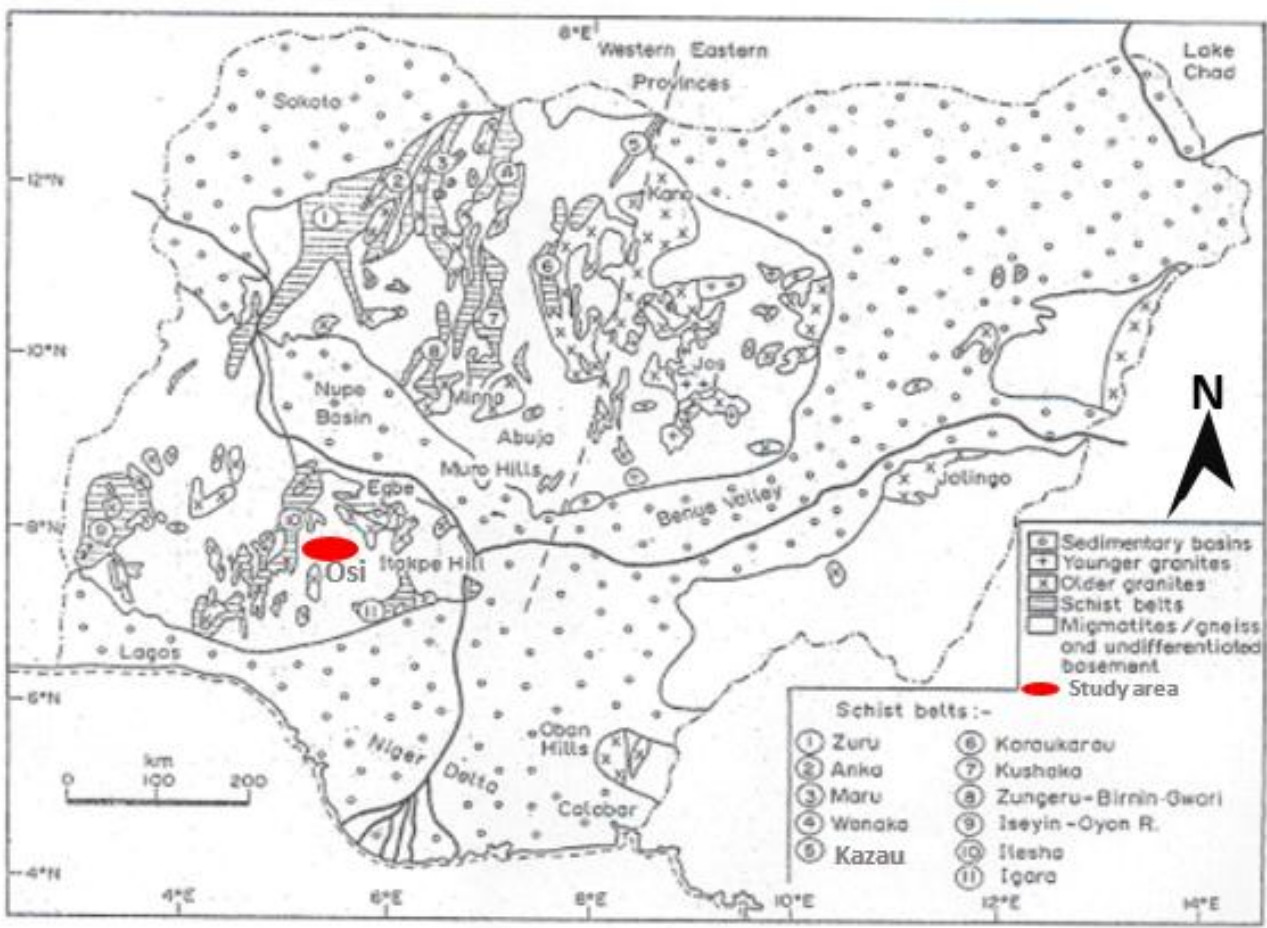

Figure 1. Generalized geological map of Nigeria showing the Basement Complex rocks provinces and the study location, Osi (modified after Rahaman, 1988)

\section{MATERIALS AND METHODS}

This study employed field observations, petrographic analysis and granulometric analysis to establish the geology, geochemical properties of the rocks, and the relationship between the rocks and the superficial deposits. Outcrop mapping and descriptions and collection of representative samples (Figure 2) from the exposed rocks was carried out in the area. Thin sections of 10 rock samples were carefully prepared and studied under petrological microscope in order to realise the mineralogy and fabrics of the rocks. While $X$ ray Fluorescence (XRF) spectrometry and inductively coupled Plasma Mass Spectrometry (ICP - MS) (for quantitative elemental abundance analysis) and granulometric analysis was performed on 12 soil samples that were collected mainly from the base of rock outcrops and from some accessible river channels in the area using set of sieve pans. 


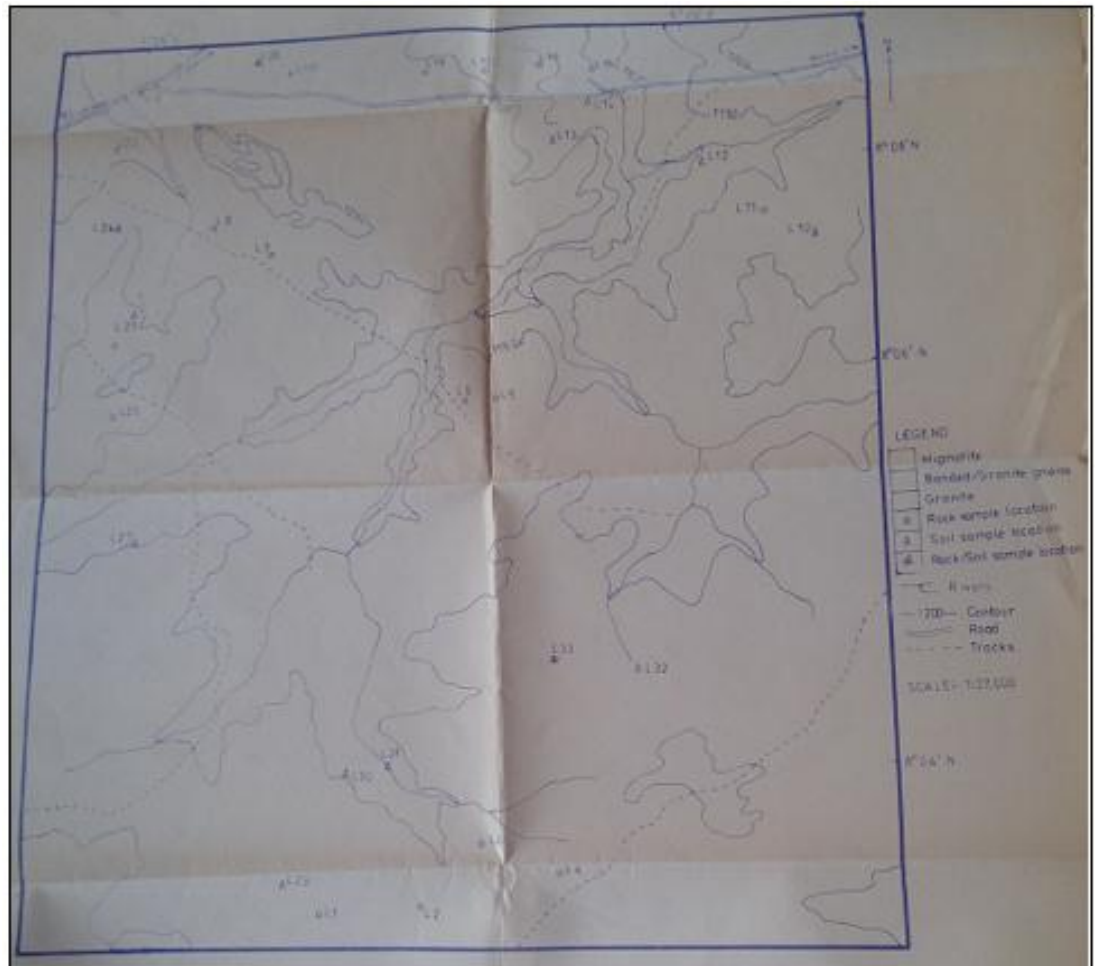

Figure 2. Topographical map of part of Osi SE (Sheet 224, Southwestern Nigeria) showing sample locations

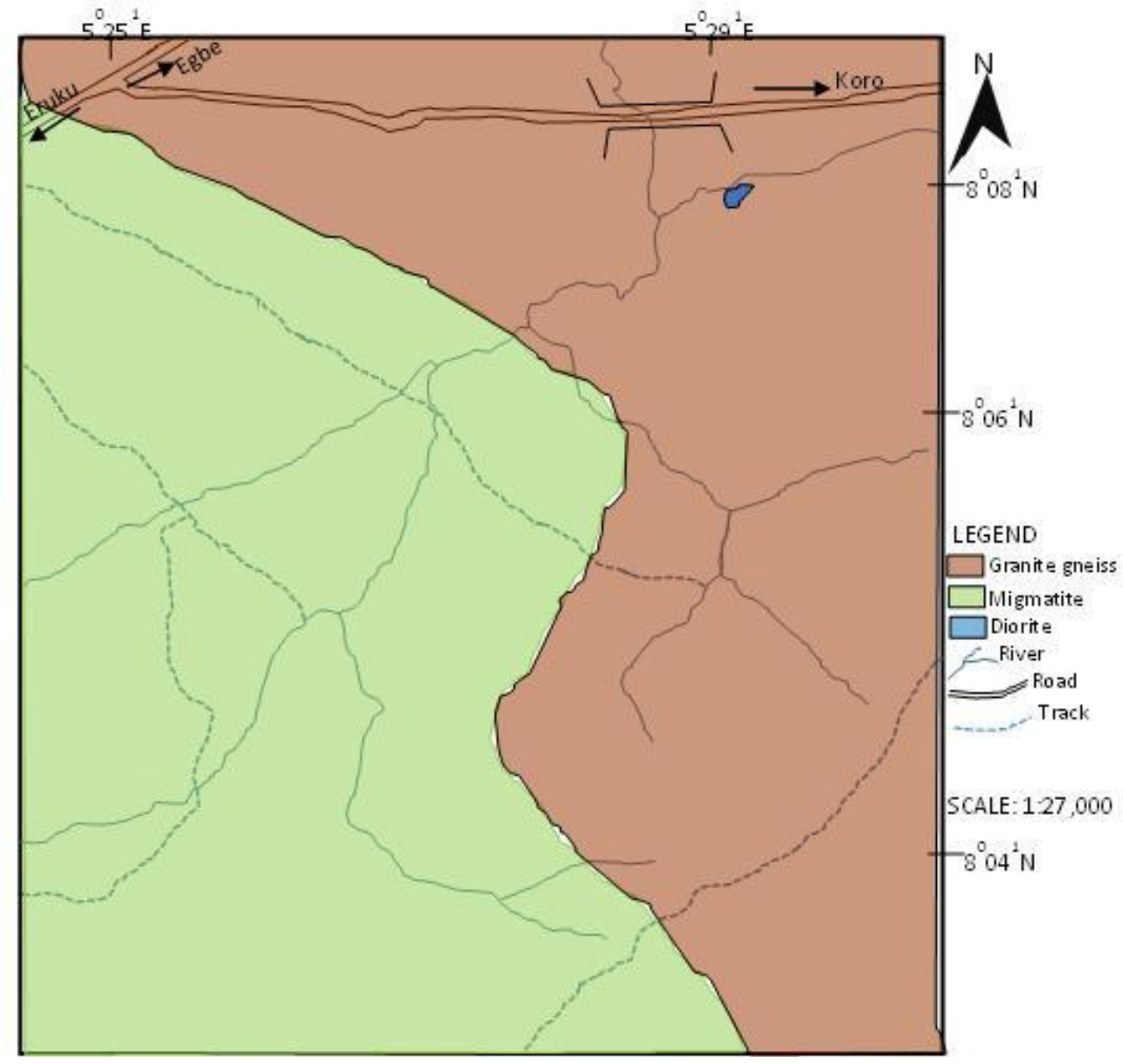

Figure 3: Geological map of part of Osi (Sheet 224, Southwestern Nigeria) 


\section{RESULTS AND DISCUSSION}

The results of the thin section study conducted are presented in Figure 4. The most common rock types in the study area include migmatite, banded gneiss, granite and an isolated diorite (Figure 3) ridge. A representative display of the petrography of the rocks in the study area is presented in figure 4 . The main components are quartz, Feldspar (Microcline and Plagioclase), Mica, Hornblende and some opaque minerals. From the analysis, quartz represents the predominant mineral component of the rocks occurring with the highest percentage in granite $(>40 \%)$ and lowest in the diorite where it averages $10 \%$ in aggregate rock composition. Microcline are most dominant in the migmatites and granite gneisses ranging from $25 \%$ - 40\%; they likely indicate granite origin (Imaseun et al., 2013). This class of mineral assemblage indicates emplacement in continental environment (Ayodele, 2015).

The soil samples and stream sediments analysed are characteristically brown to darkbrown in colour and are micaceous. They contain predominantly quartz and varying degree of feldspar. Rock fragments were also common in the stream sediments.
The results of the sieve analysis of the stream sediments (Tables 1, 2 and 3) were used to create the histogram plots (Figure 5) and cumulative frequency curves (not shown in this paper) from which Phi values were derived for evaluating the graphic means, sorting and the kurtosis that were used for the grain size analysis of the sediments in the immediate vicinity of the crystalline outcrops. Most of the samples (see Figure 5) have their modal classes between grain sizes $0.075 \mathrm{~mm}$ to $0.25 \mathrm{~mm}$ and between $0.25 \mathrm{~mm}$ to $0.5 \mathrm{~mm}$ which correlate with medium - coarse grained sands. From the tables and plots, a graphic mean of range of $-0.37-1.40$ (Table 2) interpreted using the Udden - Wentworth scale (1922) indicated medium sand to very coarse sediments. The grains generally range between very poorly sorted to poorly sorted, and mostly very leptokurtic to leptokurtic with a few showing platy kurtosis. About $35 \%$ of the grains are nearly symmetrically skewed, $25 \%$ negatively skewed, another $35 \%$ are positively skewed while $5 \%$ are strongly coarse skewed. This skewness indicates that sediments are products of in-situ weathering that were deposited proximal to the source.

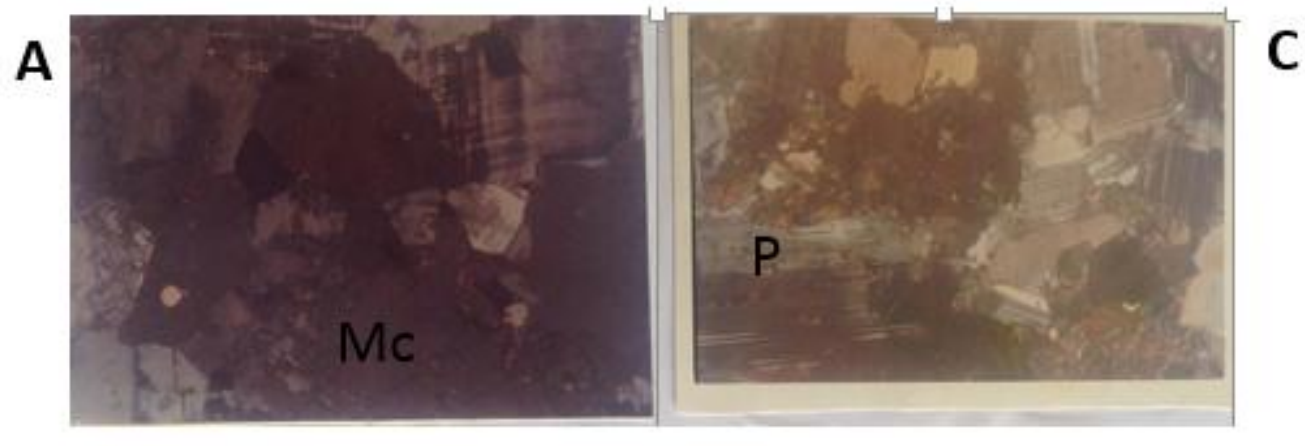

B

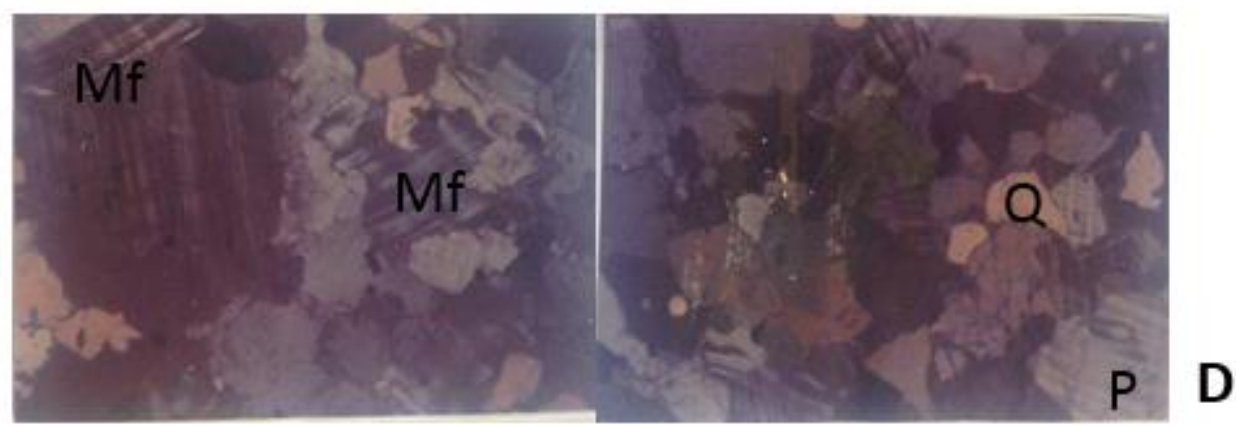

Figure 4. Petrography of some of the rocks in the study area (magnification $x 40$ ): A and B represent migmatite-gneiss rocks; $C=$ Diorite; $D=$ Granite. $M c=$ muscovite; $M f=$ Microcline feldspar; $P=$ Plagioclase; $\mathrm{Q}=$ Quartz 
Table 1. Results of sieve analysis conducted on 12 stream sediment samples collected from the area

\begin{tabular}{|l|r|r|r|r|r|r|r|}
\hline Sample/Retained weight(\%) & $1 \mathrm{~mm}$ & $0.5 \mathrm{~mm}$ & $0.25 \mathrm{~mm}$ & $0.075 \mathrm{~mm}$ & $<.075 \mathrm{~mm}$ Total (\%) \\
\hline SS 10 & 14.8 & 26.5 & 33 & 22.5 & 3 & 99.8 \\
\hline SS13 & 9 & 24 & 39 & 26 & 1 & 99 \\
\hline SS 14 & 24 & 57 & 17 & 1 & 0.5 & 99.5 \\
\hline SS 20 & 35 & 25 & 21 & 15.5 & 3 & 99.5 \\
\hline SS 24 & 11.5 & 28 & 34 & 22 & 4 & 99.5 \\
\hline SS 25 & 20.5 & 32.3 & 24 & 18 & 5 & 99.8 \\
\hline SS 27 & 34.7 & 24 & 22 & 15 & 4.2 & 99.9 \\
\hline SS 29 & 8.5 & 22 & 32 & 30 & 6 & 98.5 \\
\hline SS 30 & 23 & 28.5 & 27.5 & 18 & 2.5 & 99.5 \\
\hline SS 31 & 31 & 23 & 25 & 19 & 1 & 99 \\
\hline SS 32 & 37 & 19 & 15.7 & 23 & 5 & 99.7 \\
\hline SS 33 & 24 & 14.3 & 25 & 29 & 7.5 & 99.8 \\
\hline
\end{tabular}

Key: SS = Stream sediments

Table 2. Left: Calculated graphic properties of the stream sediments; Right: Estimated Phi values from cumulative frequency curves

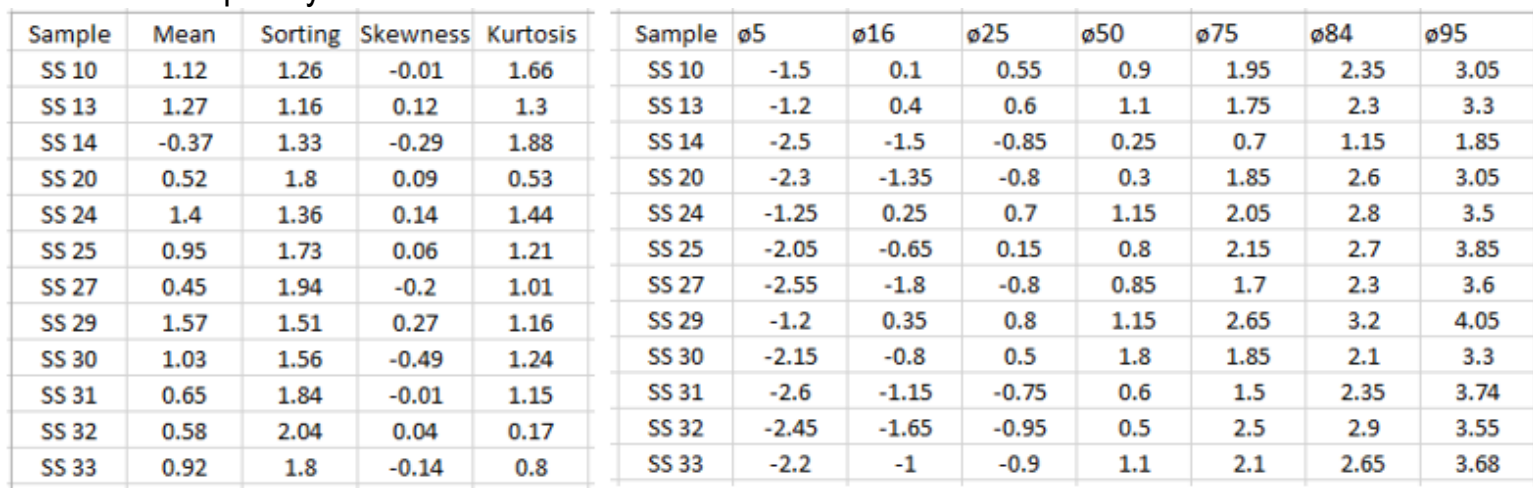

Table 3. Grain size characteristics and interpretation of the analysed stream sediments and soil samples in the area

\begin{tabular}{|l|l|l|l|l|}
\hline Sample & Graphic mean & Inclusive standard deviation & Inclusive graphic skewness & Graphic kurtosis \\
\hline SS 10 & Medium sand & Poorly sorted & Nearly symmetrical & Very leptokurtic \\
\hline SS13 & Medium sand & Poorly sorted & Positively skewed & Very leptokurtic \\
\hline SS 14 & Very coarse sand & Poorly sorted & Negatively skewed & Very leptokurtic \\
\hline SS 20 & Coarse sand & Poorly sorted & Nearly symmetrical & very platykurtic \\
\hline SS 24 & Medium sand & Poorly sorted & Positively skewed & Leptokurtic \\
\hline SS 25 & Coarse sand & Poorly sorted & Nearly symmetrical & Leptokurtic \\
\hline SS 27 & Coarse sand & Poorly sorted & Negatively skewed & Mesokurtic \\
\hline SS 29 & Medium sand & Poorly sorted & Positively skewed & Leptokurtic \\
\hline SS 30 & Medium sand & Poorly sorted & Strongly coarse skewed & Leptokurtic \\
\hline SS 31 & Coarse sand & Poorly sorted & Nearly symmetrical & Leptokurtic \\
\hline SS 32 & Coarse sand & Very poorly sorted & very positively skewed & Platykurtic \\
\hline SS 33 & Coarse sand & Poorly sorted & Negatively skewed & Platykurtic \\
\hline
\end{tabular}


Table 4. Comparison of elemental abundance of the samples ( $A=$ rocks $/$ samples; $B=$ the crust's composition)

\begin{tabular}{|l|r|r|l|l|l|r|r|r|}
\hline Element & $\mathrm{A}(\mathrm{ppm})$ & $\mathrm{B}(\mathrm{ppm})$ & $\mathrm{B} / \mathrm{A}$ & & Element & A (PPM) & $\mathrm{B}$ (PPM) & $\mathrm{B} / \mathrm{A}$ \\
\hline $\mathrm{K}$ & 23900 & 19420 & 0.81 & & $\mathrm{~K}$ & 17200 & 19420 & 1.13 \\
\hline $\mathrm{Ca}$ & 23700 & 49960 & 2.11 & $\mathrm{Ca}$ & 14000 & 49960 & 3.57 \\
\hline $\mathrm{Ti}$ & 3810 & 5040 & 1.32 & $\mathrm{Ti}$ & 12100 & 5040 & 0.42 \\
\hline $\mathrm{Cr}$ & 907 & 102 & 0.11 & $\mathrm{Mn}$ & 773 & 1240 & 1.6 \\
\hline $\mathrm{Mn}$ & 873 & 1240 & 1.42 & $\mathrm{Fe}$ & 32700 & 50880 & 1.56 \\
\hline $\mathrm{Fe}$ & 32000 & 50880 & 1.59 & $\mathrm{Cu}$ & 149 & 68 & 0.46 \\
\hline $\mathrm{Cu}$ & 162 & 68 & 0.42 & $\mathrm{~Pb}$ & 95.3 & 13 & 0.14 \\
\hline $\mathrm{Zn}$ & 131 & 76 & 0.42 & $\mathrm{Rb}$ & 94.2 & 78 & 0.83 \\
\hline $\mathrm{Pb}$ & 74.1 & 13 & 0.18 & $\mathrm{Sr}$ & 31.1 & 384 & 12.3 \\
\hline $\mathrm{Rb}$ & 247 & 78 & 0.32 & $\mathrm{Y}$ & 57.6 & 3.1 & 0.54 \\
\hline $\mathrm{Sr}$ & 264 & 384 & 1.45 & $\mathrm{Zr}$ & 500 & 162 & 0.32 \\
\hline $\mathrm{Th}$ & 35.6 & 8.1 & 0.23 & $\mathrm{Nb}$ & 14 & 20 & 1.43 \\
\hline $\mathrm{Y}$ & 22.7 & 31 & 1.37 & & & & \\
\hline $\mathrm{U}$ & 35.1 & 2.7 & 0.08 & & & & & \\
\hline $\mathrm{Zr}$ & 241 & 162 & 0.67 & & & & & \\
\hline $\mathrm{Nb}$ & 30.3 & 20 & 0.66 & & & & & \\
\hline
\end{tabular}

Table 5. ICP - MS analysis of some samples digested with acids (2 L35 PS = pegmatite; 2 L29 SS = soil sample; $2 \mathrm{~L} 11 \mathrm{M}=$ Muscovite; $2 \mathrm{~L} 21 \mathrm{~F}=$ Feldspar

\begin{tabular}{|c|c|c|c|c|}
\hline Element & Conc (ppm) (2 L35 PS) & Conc (ppm) (2 L29 SS) & Conc $(p p m)(2 \mathrm{~L} 11 \mathrm{M})$ & Conc $(\mathrm{ppm})(2 \mathrm{~L} 21 \mathrm{~F})$ \\
\hline$Y$ & 14.9 & 7.8 & 0.7 & 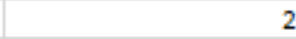 \\
\hline $\mathrm{Ce}$ & 59.54 & 69.69 & 3.64 & 0.59 \\
\hline $\mathrm{Pr}$ & 4.9 & 6.6 & 0.3 & 0.1 \\
\hline Nd & 17.6 & 23.9 & 1.2 & 0.3 \\
\hline Sm & 3.8 & 5.2 & 0.3 & 0.1 \\
\hline Eu & 0.7 & 0.5 & $<0.1$ & 0.2 \\
\hline Gd & 2.5 & 3.2 & 0.3 & 0.1 \\
\hline Tb & 0.4 & 0.4 & 0.08 & 0.09 \\
\hline Dy & 2.5 & 1.9 & 0.2 & 0.3 \\
\hline Ho & 0.5 & 0.3 & 0.1 & $<0.1$ \\
\hline Er & 2.2 & 0.8 & 0.1 & 0.5 \\
\hline Tm & 0.3 & 0.1 & 0.09 & 0.08 \\
\hline Yb & 2.7 & 0.8 & 0.1 & 0.5 \\
\hline Lu & 0.4 & 0.1 & 0.09 & 0.1 \\
\hline $\mathrm{Hf}$ & 3.14 & 2.33 & 0.64 & 0.09 \\
\hline Li & 30.2 & 3.9 & 121 & 15.7 \\
\hline $\mathrm{Rb}$ & 195.4 & 126.1 & 954.7 & 576.1 \\
\hline $\mathrm{Ta}$ & 2 & 1.1 & 29.3 & 0.8 \\
\hline $\mathrm{Nb}$ & 13.4 & 9.86 & 227.84 & 2.11 \\
\hline $\mathrm{Cs}$ & 4.9 & 1.8 & 49.9 & 3.6 \\
\hline $\mathrm{Ga}$ & 17.35 & 8.48 & 101 & 19.18 \\
\hline $\mathrm{Ca}$ & 1.48 & 0.22 & 0.04 & 0.17 \\
\hline $\mathrm{P}$ & 0.021 & 0.015 & 0.013 & 0.003 \\
\hline $\mathrm{Mg}$ & 0.45 & 0.06 & 0.47 & 0.01 \\
\hline $\mathrm{Fe}$ & 2.27 & 0.85 & 1.85 & 0.05 \\
\hline $\mathrm{Ba}$ & 755 & 954 & 95 & 226 \\
\hline $\mathrm{Ti}$ & 0.253 & 0.331 & 0.188 & 0.001 \\
\hline Al & 5.84 & 4.32 & 18.39 & 8.86 \\
\hline $\mathrm{Na}$ & 1.81 & 0.408 & 0.567 & 1.802 \\
\hline K & 2.59 & 3.68 & 9.71 & 11 \\
\hline
\end{tabular}


Lawal et al: Integrated Geology and Geochemical Analysis of Eruku Basement Complex

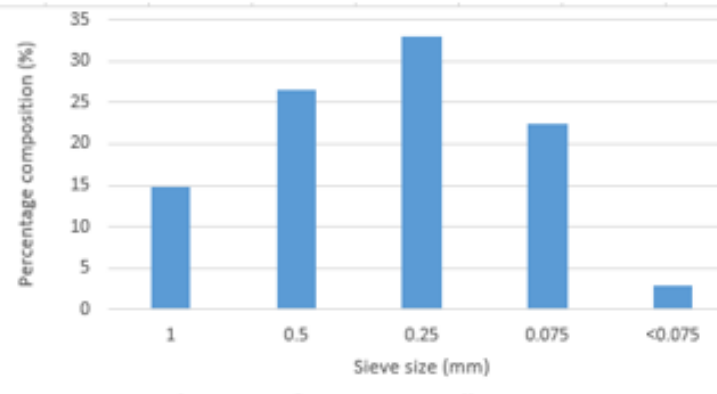

Histogram for stream sediment 10

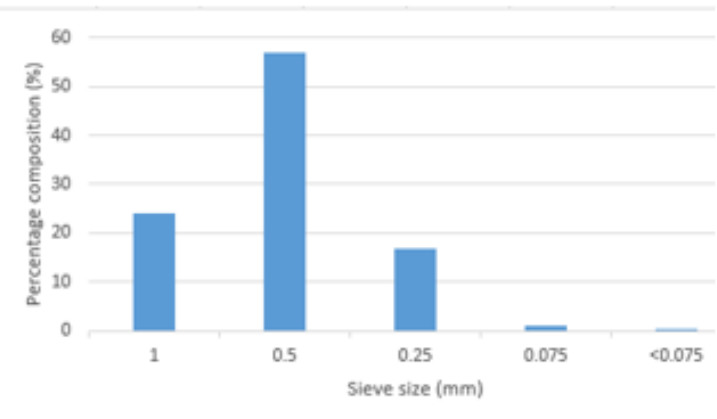

Histogram for stream sediment 14

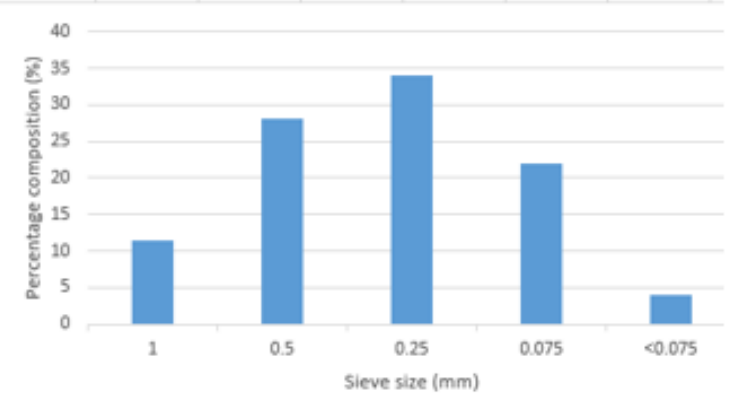

Histogram for stream sediment 24

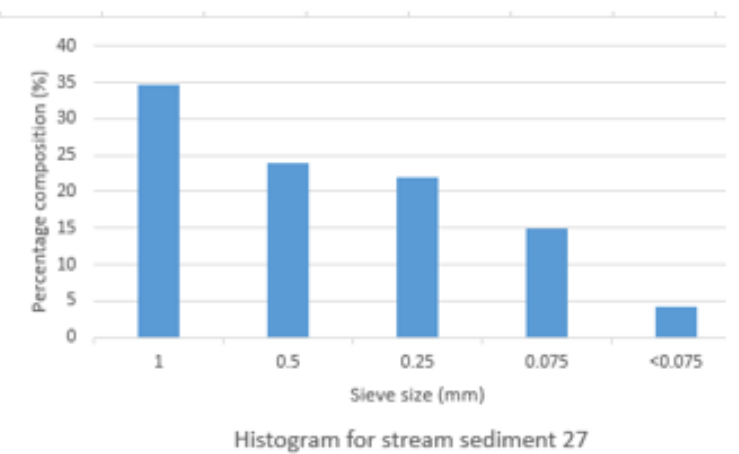

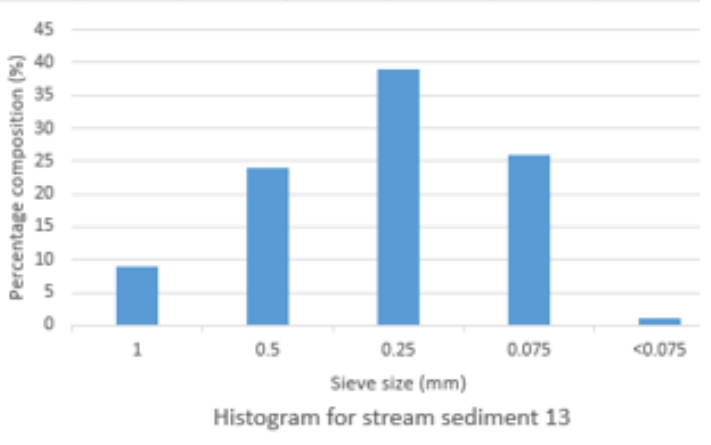

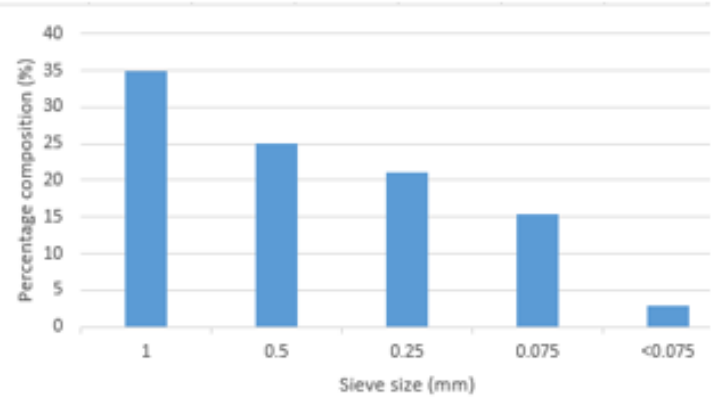

Histogram for stream sediment 20

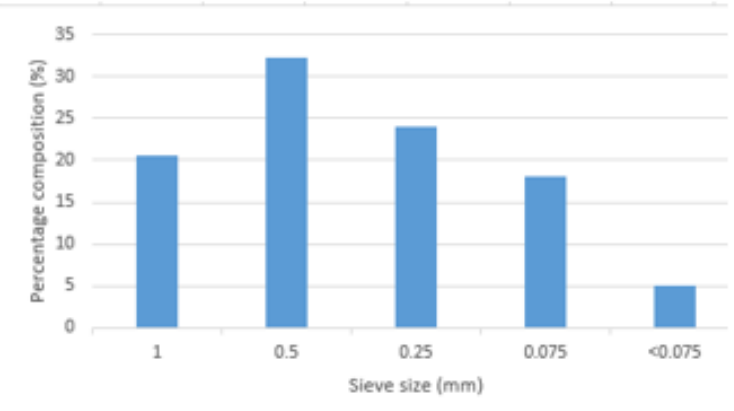

Histogram for stream sediment 25

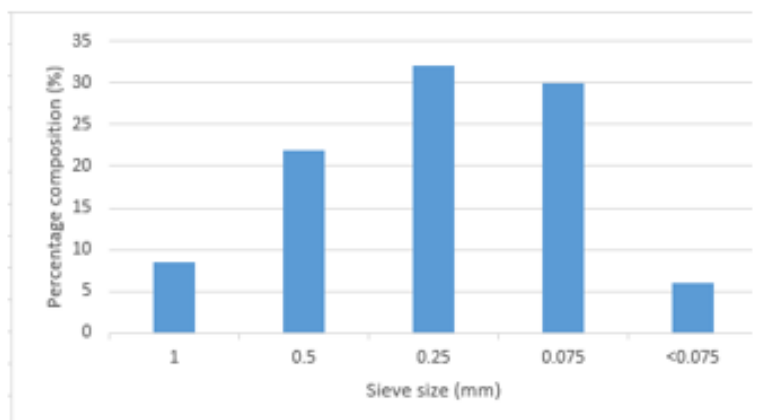

Histogram for stream sediment 29 

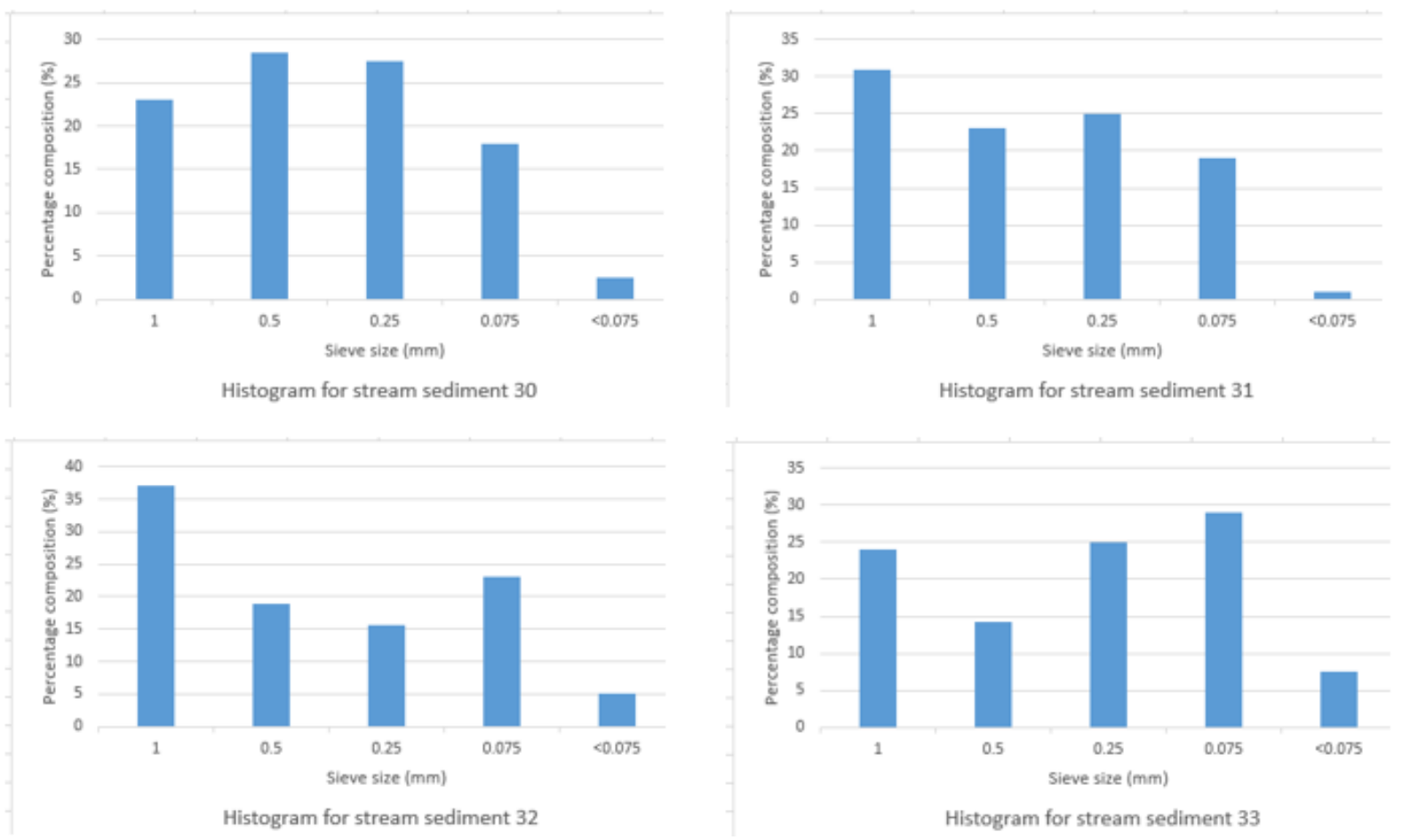

Figure 5. Histogram plots of the grain size analysis of the selected stream sediments in the area. The predominant grain sizes is $0.25-0.5 \mathrm{~mm}$ indicating coarse - very coarse grained deposits; the least common grain size is $<0.075-0.075 \mathrm{~mm}$.

Representative XRF results (Tables 4 and 5) and the ICP-MS, whose results are presented in Table 5 , is a quantitative technique that assists in subdivision of the elements as major, minor and trace elements and it agrees with Goldschmidts (1954) division of elemental compositions of rocks into major elements (those that have their elemental composition greater than their presence in the crust) and minor elements (referring those elements whose sample composition is greater than their presence in the crust). The major elements in the analysed samples include $\mathrm{Fe}, \mathrm{Ca}, \mathrm{Mg}, \mathrm{Al}$, $\mathrm{Ti}, \mathrm{Na}, \mathrm{K}$ and $\mathrm{S}$; these are present in concentrations $>1000 \mathrm{ppm}$ i.e. $>1 \%$. Also noticed is relatively elevated level of $\mathrm{Ba}$ and $\mathrm{Rb}$. The method is useful as guide to regional mapping, applicable to Basement complex geochemistry (e.g., Ayodele, 2015) and in geochemical prospecting of minerals like gold, platinum, etc. (Rose, 1974).

\section{CONCLUSION}

Eruku area of Osi, Southwestern Nigeria exhibited typical geology of the Nigerian Basement complex characterized by the predominance of migmatite - gneiss complex that indicated continental origin. Combination of petrography, granulometry and the ICP-MS techniques were applied to describe the geology and elemental composition of the rocks in the area. Granulometric analysis of adjacent stream sediments showed coarse - very coarse sediments with very poorly to poorly sorted grains. This indicated sediment derivation from proximal weathering of the parent crystalline rocks.

The XRF and ICP-MS analysis divided the elemental abundance of the rocks major and minor elements. This integrated analysis is not only complementary to and useful in regional mapping of the Nigerian Basement complex but also applicable to geochemical mineral exploration.

\section{REFERENCES}

Ajibade AC, Wright JB (1989). The TogoBenin, Nigeria shieldevidence of crustal aggregation in pan African belt. Tectonophysics, 155

Ajibade, A.C. (1987). The Origin of older granites of Nigeria. Some evidences 
from Zungeru region. Nigeria Journal, Mineral and Geology, 2(2): 223-230.

Anifowose, A.Y.B. and Borode, A.M., (2007). Photogeological study of the fold structure in Okemesi area, southwestern Nigeria. Journal of Mining and Geology. 43(2): pp. 125130.

Annor, E.A., (1986). A structural classification of the Precambrian basement complex of Nigeria. Journal of Mining and Geology. 7(2): 42-47.

Ayodele, S.O. (2015). The geology, geochemistry and petrogenetic studies of the Precambrian Basement rocks around Iworoko, Are and Afao area, Southwestern Nigeria. Journal of Environment and Earth Science. 5(3): 58-66.

Dada, S.S., and Rahaman, M.A. (1995). Archean-Lower Paleozoic Crustal evolution in Nigeria. African Geoscience Review, 2: 219-225.

Grant N.K. (1969). The late Precambrian to early Palaeozoic Pan African Orogeny in Ghana, Togo, Dahomey and Nigeria Geological Society of America. Bulleting, 80(1): 45-56.

Goldschmidts, V.M. (1954). Geochemistry. In Rhodes W. F. (ed), Encyclopedia of Geochemistry and Environmental Science. Volume IV. A dowden Hutchinson and Ross, Inc. New York, pp. $395-398$.

Imaseun, O.I., Olatunji, J.A., and Oyenubi, T.U.S. (2013). Geological Observation of Basement rocks around Gangu, Kogi State. International Research Journal of Geology and Mining, 3(2): 57

Kennedy, W.Q. (1964). The structural differentiation of Africa in the Pan African $\pm 500 \mathrm{Ma}$. tectonic episode, In: 8th Annual Report of the Research Institute of African Geology, Leeds University, UK, 128.
Odeyemi, I.B., Anifowose, A.Y.B., and AsiwajuBello, Y.A., (1999). Multi-technique graphical analysis of fractures from remotely-sensed images of basement region of Nigeria. Journal of Mining and Geology, 35(1) pp. 9-21.

Oversby, V. (1975). Lead isotopic systematics and ages of Archaean acid intrusives in the Kalgoorlie-Norseman area, Western Australia. Journal of Geochemistry, Cosmochimica Acta, 39(8): 1107-1125.

Oyawoye M.O. (1972). The basement complex of Nigeria in African Geology edited by T. F. J Dessau Vagie and Whiteman, A.J. Whiteman. University of Ibadan Press 66-102.

Rahaman M.A (1976). Review of the basement geology of south western Nigeria in Geology of Nigeria edited by C. A Kogbe. Elizabeathan pub. co, Lagos; 41-58.

Rahman, A. M.S., Ekwere, S.J., Azmatullah, M. and Ukpong, E.E. (1988). Petrology and Geochemistry of granitic intrusive rocks from the western part of the Oban massif, southeastern Nigeria. Journal of African Earth Sciences (and the Middle East), 7(1): 149 - 157.

Rose, A.W. (1974). The mode of occurrence of trace elements in soil and stream sediments applied Geological Exploration Development in Economic Geology. Journal of Geochemical Exploration. 1: 691 - 705

Wentworth, C.U. (1992). A scale of grade terms for clastic sediments. Journal of Geology. 20: 377 - 392 